\title{
Toll-Like Receptor 2-Independent and MyD88-Dependent Gene Expression in the Mouse Brain
}

\author{
Gaëlle Naert Nathalie Laflamme Serge Rivest \\ Laboratory of Molecular Endocrinology, CHUL Research Center and Department of Anatomy and Physiology, \\ Laval University, Québec, Qué., Canada
}

\section{Key Words}

Chemokines $\cdot$ Cytokines $\cdot$ Inflammation • Innate immunity • Lipopolysaccharide $\cdot$ Microglia $\cdot$ NF- $\mathrm{B}$

\begin{abstract}
Toll-like receptors (TLRs) are essential to mount a rapid innate immune reaction to pathogens. Although TLR2 is the key receptor for pathogen-associated molecular patterns from Gram-positive bacteria, a robust transcriptional activation of the gene encoding this receptor takes place in the brain of mice exposed to the TLR4 ligand lipopolysaccharide (LPS). TLR2 gene expression is actually used as a reliable marker of activated microglia in vivo, but its functions remain unknown. The present study investigated the role of this receptor in mediating LPS-induced gene expression in the mouse brain. Immune genes were measured using both in situ hybridization and real time RT-PCR. Despite the robust microglial TLR2 expression, this receptor does not modulate transcriptional activity by TLR4 signaling. TLR2-deficient mice and their wild-type littermates had similar $1 \kappa B \alpha$ mRNA levels and induction of innate immune genes from $6 \mathrm{~h}$ to 10 days after LPS injection. In contrast, NF- $\kappa$ B activity, cytokine, chemokine, TLR2 and CD14 transcripts were no longer detected in MyD88-deficient mice. Indeed, the hybridization signal for most of the transcripts measured in this study was similar in the brain of MyD88 ${ }^{-/-}$mice exposed to either saline or LPS. These data indicate that while TLR2 transcription is dependent on MyD88 signaling in microglia, this innate im-
\end{abstract}

mune receptor is not involved in the immune response to LPS. On the other hand, MyD88 pathway is essential for the endotoxin to induce expression of immune genes in the central nervous system.

Copyright $\odot 2009$ S. Karger AG, Basel

\section{Introduction}

Innate immunity is the early response of the host to infection. It is characterized by a cascade of proinflammatory signaling events and transcriptional activation of several immune-related genes. The presence of infection is recognized by receptors for specific elements called the pathogen-associated molecular patterns, which represent the first step of the innate immune response $[1,2]$. The major pathogen-associated molecular patterns produced by bacteria and viruses are recognized by the Toll-like receptor (TLR) family, first discovered in Drosophila. Mammalian TLRs are mainly expressed in cells of the innate immune system, and ligands that bind to them trigger proinflammatory signal transduction pathways and gene transcription $[1,2]$. In the pathological central nervous system (CNS), TLRs are found prominently on microglia and invading macrophages [3]. Microglia, the resident innate immune effector cells of the CNS parenchyma, represent a first line of defense against invading pathogens [4] and express most of the TLRs (TLR1-9) [5]. To date, the TLR family includes a total of 13 members [6, 7]. TLR2 
recognizes the widest array of pathogen-associated molecular patterns, in heterodimeric complexes with either TLR1 or TLR6, including lipoproteins and peptidoglycan that are components of all bacteria possessing cell walls as well as lipoteichoic acid from the cell wall of Gram-positive bacteria [6-12]. TLR4 recognizes the endotoxin lipopolysaccharide (LPS), a major component of the outer membranes of Gram-negative bacteria [13, 14], which is the best characterized example of innate recognition associated with a robust inflammatory response by the antigen-presenting cells, macrophages and dendritic cells, and in the brain microglia [15]. LPS binding to TLR4 occurs through the TLR4/MD2/CD14 complex [2, 6, 16, 17]. In fact, CD14 is another transmembrane receptor for LPS and LPS stimulation is followed by an increased physical proximity between TLR4 and CD14 [12]. Unlike TLR2, proinflammatory signaling requires homodimerization of the TLR4 cytoplasmic domain $[6,12]$.

TLR-induced inflammatory response is dependent on a common signaling pathway that is mediated by the adaptor molecule MyD88, which is utilized by all TLRs except TLR3 [2]. MyD88 signaling induces activity of the NF- $\kappa \mathrm{B}$ transduction pathway, resulting in the expression of innate immune genes, such as tumor necrosis factor $\alpha$ (TNF- $\alpha$ ), interleukin 6 (IL-6) and IL-1 $1 \beta$. Interestingly, both the IL-1 and IL-18 receptors also use MyD88 to induce NF- $\kappa \mathrm{B}$ signaling [8]. In fact, TLRs, IL-1R and IL18R share the same cytoplasmic domain, the Toll/IL-1 receptor homologous (TIR) domain [6, 7].

These events also take place in the CNS. Circulating LPS can reach the circumventricular organs, leptomeninges and choroid plexus, bind to TLR4 and CD14 and stimulate gene expression in resident macrophages and microglia [18-20]. This is also the case when the endotoxin is administered directly within the cerebral tissue in a CD14- and TLR4-dependent manner [5, 19, 21]. Interestingly, LPS is able to cause a robust transcriptional induction of TLR2 in the brain [20,22,23], but the physiological relevance of this phenomenon has yet to be uncovered.

The goal of this study was to characterize the profile and pattern of TLR2 gene expression in the mouse brain exposed to the TLR4 ligand LPS. We then investigated the potential role of this receptor in the LPS signaling in TLR2-deficient mice. Our systematic study presents the variations of major genes implicated in innate immune response at different times ( $6 \mathrm{~h}, 24 \mathrm{~h}$ and 2, 4 and 10 days) after a single LPS bolus. Despite the strong increase of TLR2 in microglia, this receptor is not involved in the activation of immune genes in the CNS of LPS-treated mice. We then determined whether TLR2 gene transcrip- tional regulation was mediated by the canonical LPS response (e.g. MyD88). MyD88 ${ }^{-/-}$animals were resistant to intracerebral LPS exposure and they did not mount an innate immune reaction to the endotoxin. These data suggest that MyD88 plays a critical role in the transcriptional activation of immune genes, including TLR2 in microglia. However, this receptor does not modulate the immune response to TLR4 signaling in the brain.

\section{Materials and Methods}

\section{Animals}

We used adult male C57BL/6 mice (wild type, WT), TLR2 knockout (KO) mice and MyD88 KO mice (6 weeks of age, 22-25 g b.w.). TLR2-deficient mice were obtained from the Jackson Laboratory (B6.129-Tlr2tm1Kir/J [24]). MyD88 ${ }^{-1-}$ mice (C57BL/6 background) were maintained as a colony from breeders originally donated by Dr. Shizuo Akira (Department of Host Defense, Research Institute for Microbial Diseases, Osaka University, Osaka, Japan) $[8,25]$.

A total of $106 \mathrm{WT}, 31 \mathrm{TLR} 2 \mathrm{KO}$ and $75 \mathrm{MyD} 88 \mathrm{KO}$ mice were assigned to vehicle or LPS injection and killed at different times after injection ( 6 and $24 \mathrm{~h}$ and 2, 4 and 10 days). Mice were acclimated to standard laboratory conditions (12-hour light, 12-hour dark cycle; lights on at 07:00 and off at 19:00) with free access to mouse chow and water. Animal breeding and experiments were conducted according to Canadian Council on Animal Care guidelines, as administered by the Laval University animal care committee.

Intracerebral Injections

On the day of the experiment, animals were anesthetized with isoflurane and the site of injection was stereotaxically reached (David Kopf Instruments, Tujunga, Calif., USA). One microliter of endotoxin LPS ( $1 \mu \mathrm{g} / \mu \mathrm{l}$; from Escherichia coli, serotype 055:B5; Sigma-Aldrich) or the vehicle solution (sterile pyrogen-free $0.9 \%$ saline) was injected over a period of $2 \mathrm{~min}$ into the left striatal region at coordinates from the bregma (anteroposterior $0 \mathrm{~mm}$, lateral $-2 \mathrm{~mm}$ and dorsoventral $-3 \mathrm{~mm}$ ) according to Paxinos and Franklin Atlas [26].

Six and $24 \mathrm{~h}$ and 2, 4 and 10 days after the single injection, animals were deeply anesthetized with an i.p. injection of a mixture of ketamine hydrochloride $(91 \mathrm{mg} / \mathrm{ml})$ and xylazine $(9 \mathrm{mg} /$ $\mathrm{ml}$ ) and then rapidly perfused transcardially with $0.9 \%$ saline, followed by $4 \%$ paraformaldehyde in $0.1 \mathrm{M}$ borax buffer ( $\mathrm{pH} 9.5$ at $4^{\circ} \mathrm{C}$ ). Brains were rapidly removed from the skulls, postfixed for 2-8 days and then placed in a solution containing $10 \%$ sucrose diluted in $4 \%$ paraformaldehyde-borax buffer overnight at $4^{\circ} \mathrm{C}$. The frozen brains were mounted on a microtome (Reichert-Jung, Cambridge Instruments Company, Deerfield, Ill., USA) and cut into 25- $\mu \mathrm{m}$ coronal sections from the olfactory bulb to the end of the medulla. The slices were collected in a cold cryoprotectant solution $(0.05 \mathrm{M}$ sodium phosphate buffer $\mathrm{pH} 7.3,30 \%$ ethylene glycol, $20 \%$ glycerol) and stored at $-20^{\circ} \mathrm{C}$.

For the real time qPCR assay, mice were deeply anesthetized and blood was drawn by cardiac puncture before head decapitation. Brains were removed rapidly from the skulls and placed in 
Table 1. Plasmids and enzymes used for the synthesis of the cRNA probes

\begin{tabular}{llllll}
\hline Mouse plasmid & Vector & Insert & Antisense probe & Sense probe & Source \\
\hline CD14 & pRc/CMV & $1.5 \mathrm{~kb}$ & Apa I/T7 & HindIII/SP6 & Dr. R. Landmann, Basel, Switzerland \\
IkB $\alpha$ & bluescript SK++ & $1.114 \mathrm{~kb}$ & BamH I/T7 & HindIIIT3 & Dr. A. Israel, Institut Pasteur, Paris, France \\
IL-12p40 & pCL-NEO & $1.05 \mathrm{~kb}$ & XhoI/T3 & NotI/T7 & Dr. K. Pahan, University of Nebraska, Lincoln, Nebr., USA \\
IL-1 $\beta$ & PCR-blunt II & $1.36 \mathrm{~kb}$ & KpnI/ T7 & XhoI/Sp6 & Dr. P.W. Gray, Genentech Inc., San Francisco, Calif., USA \\
MCP-1 & pGEM-1 & $578 \mathrm{bp}$ & BamH I/T7 & SacI/SP6 & Dr. S.C. Williams, Texas Tech U., Lubbock, Tex., USA \\
TGF $\beta 1$ & pBSKS+ & $1,173 \mathrm{bp}$ & EcoR1/T3 & XhoI/T7 & Dr. S. Lacroix, Université Laval, Québec, Qué., Canada \\
TNF- $\alpha$ & bluescript SK++ & $1.3 \mathrm{~kb}$ & PstI/T3 & BamHI/T7 & Dr. D. Radzioch, McGill University, Montreal, Que., Canada \\
TLR2 & PCR-blunt II & $2.248 \mathrm{~kb}$ & EcoRV/Sp6 & Spe/T7 & Cloned by PCR \\
\hline
\end{tabular}

sterile cold PBS solution. The left basal ganglia and cortex (limited at plane anteroposterior +1.5 to 21.5 and dorsoventral 24.0) was dissected and quickly immersed in liquid nitrogen. The tissue was stored at $-80^{\circ} \mathrm{C}$ until RNA extraction was performed.

\section{cRNA Probe Preparation and in situ Hybridization}

Histochemistry

Plasmids were linearized and the sense and antisense riboprobes synthesized with the appropriate RNA polymerase as described in table 1 . Radioactive cRNA copies were synthesized by incubation of $250 \mathrm{ng}$ linearized plasmid in $6 \mathrm{mM} \mathrm{MgCl}_{2}, 40 \mathrm{mM}$ Tris (pH 7.9), $2 \mathrm{mM}$ spermidine, $10 \mathrm{mM} \mathrm{NaCl}, 10 \mathrm{mM}$ dithiothreitol, $0.2 \mathrm{mM}$ ATP/GTP/CTP, $100 \mu \mathrm{Ci}$ of $\left[{ }^{35} \mathrm{~S}\right] \mathrm{UTP}$ (NEG 039H, Dupont NEN), 20 U RNAsin (Promega, Madison, Wisc., USA) and $10 \mathrm{U}$ of either T7, SP6 or T3 RNA polymerase for $60 \mathrm{~min}$ at $37^{\circ} \mathrm{C}$ (table 1). Unincorporated nucleotides were removed using ammonium acetate precipitation method: $100 \mu \mathrm{l}$ of DNase solution $(1 \mu \mathrm{l}$ DNase, $5 \mu \mathrm{l}$ of $5 \mathrm{mg} / \mathrm{ml}$ tRNA, $94 \mu \mathrm{l}$ of $10 \mathrm{~mm}$ Tris $/ 10 \mathrm{~mm}$ $\left.\mathrm{MgCl}_{2}\right)$ was added, and $10 \mathrm{~min}$ later a phenol-chloroform $(100 \mu \mathrm{l})$ extraction was performed. The cRNA was precipitated with $80 \mu \mathrm{l}$ of $5 \mathrm{M}$ ammonium acetate and $500 \mu \mathrm{l}$ of $100 \%$ ethanol for $20 \mathrm{~min}$ on dry ice. The pellet was dried and resuspended in $50 \mu \mathrm{l}$ of 10 $\mathrm{mM}$ Tris/1 mM EDTA. A probe containing $10^{7} \mathrm{cpm}$ was mixed into $1 \mathrm{ml}$ of hybridization solution [500 $\mu$ l formamide, $60 \mu \mathrm{l} 5 \mathrm{M}$ $\mathrm{NaCl}, 10 \mu \mathrm{l} 1 \mathrm{M}$ Tris (pH 8.0), $2 \mu \mathrm{l} 0.5 \mathrm{M}$ EDTA (pH 8.0), $50 \mu \mathrm{l}$ $20 \times$ Denhart's solution, $200 \mu 150 \%$ dextran sulfate, $50 \mu \mathrm{l} 10 \mathrm{mg} /$ $\mathrm{ml}$ tRNA, $10 \mu \mathrm{l} 1 \mathrm{M}$ dithiothreitol, (118 $\mu \mathrm{l}$ DEPC water - volume of probe used)]. This solution was mixed and heated for $10 \mathrm{~min}$ at $65^{\circ} \mathrm{C}$ before being spotted on slides. Hybridization histochemical localization of sCD14, I $\kappa \mathrm{B} \alpha$, IL-12p40, IL-1 $\beta$, MCP-1, TGF- $\beta 1$, TNF- $\alpha$ and TLR 2 mRNA was carried out on every twelfth section of the whole rostrocaudal extent of each brain using ${ }^{35} \mathrm{~S}$-labeled cRNA probes as described previously $[27,28]$. The sections were exposed at $4^{\circ} \mathrm{C}$ to X-ray films (Biomax; Kodak, Rochester, N.Y., USA) for 1-3 days. The slides were thereafter defatted in xylene, dipped in NTB-2 nuclear emulsion (Kodak; diluted 1:1 with distilled water), exposed for 10-14 days. The slides were then developed in D19 developer (Kodak) for $3.5 \mathrm{~min}$ at $14-15^{\circ} \mathrm{C}$, washed for $15 \mathrm{~s}$ in water and fixed in rapid fixer (Kodak) for $5 \mathrm{~min}$. Tissues were thereafter rinsed in running distilled water for $1 \mathrm{~h}$, counterstained with thionin $(0.25 \%)$, dehydrated through graded concentrations of alcohol, cleared in xylene, and coverslipped with distrene plasticizer xylene mounting medium (Electron Microscopy Science, Washington, Pa., USA).
Immunocytochemistry was combined with the in situ hybridization histochemistry protocol to label cytokine transcripts in microglia [18].

\section{Quantitative Analysis}

Quantitative analysis of the hybridization signal was carried out on X-ray films (Biomax, Kodak) over 4 brain sections adjacent to the site of LPS injection. Four sections were chosen for the analysis of optical density (OD) and labeled surface area using ImageJ software, as previously described $[18,19]$. Data are reported as mean OD values and mean of labeled surface area (mean \pm SEM).

\section{Quantitative RT-PCR Analysis}

Total RNA was isolated for each condition and time point using the Trizol reagent method, according to the manufacturer's protocol (Sigma) and then digested with deoxyribonuclease to remove any contaminating genomic DNA (Turbo DNA-free; Ambion, Austin, Tex., USA). RNA quantity and quality was assessed using a 2100 bioanalyzer and RNA 6000 Nano LabChip kit (Agilent, Mountain View, Calif., USA). Complementary DNA (cDNA) was generated from $40 \mathrm{ng}$ of total RNA using a random primer hexamer following the protocol for Superscript II (Invitrogen, Carlsbad, Calif., USA). Equal amounts of cDNA were run in triplicate and amplified in a $15-\mu l$ reaction containing $7.5 \mu l$ of $2 \times$ Universal PCR Master Mix (Applied Biosystems, Foster City, Calif., USA), $10 \mathrm{nM}$ of Z-tailed forward primer, $100 \mathrm{nM}$ of reverse primer, 250 nM of Amplifluor Uniprimer probe (Chemicon, Temecula, Calif., USA), and $1 \mu \mathrm{l}$ of cDNA target. Moreover, no-template controls were used as recommended. The mixture was incubated at $50^{\circ} \mathrm{C}$ for $2 \mathrm{~min}, 95^{\circ} \mathrm{C}$ for $4 \mathrm{~min}$, and then cycled at $95^{\circ} \mathrm{C}$ for $15 \mathrm{~s}$ and at $55^{\circ} \mathrm{C}$ for 30 s 55 times using the Applied Biosystems Prism 7900 Sequence Detector. Amplification efficiencies were validated and normalized to ribosomal $18 \mathrm{~S}$ gene and quantity of target gene was calculated according to a standard curve. Primers sequences were designed using Primer Express 2.0 (Applied Biosystems) and are described in table 2. Amplicons were detected using the Amplifluor UniPrimer system, in which forward primers used contained a 5' Z sequence ACTGAACCTGACCGTACA.

\section{Statistical Analyses}

Statistical analysis was performed by ANOVA for each transcript, followed by a Bonferroni test procedure as post-hoc comparisons with Prism software. 
Table 2. Sequences of primers used for the real time PCR

\begin{tabular}{llll}
\hline Mouse gene & Accession number & Forward primer $\left(5^{\prime}-3^{\prime}\right)$ & Reverse primer $\left(5^{\prime}-3^{\prime}\right)$ \\
\hline IкB $\alpha$ & NM_010907 & ACTGAACCTGACCGTACAGAGGACGGAGACTCGTTCCTG & CGGCTTCTCTTCGTGGATGA \\
IL-1 $\beta$ & NM_008361 & ACTGAACCTGACCGTACACCAAAAGATGAAGGGCTGCT & TCATCTGGACAGCCCAGGTC \\
IL-6 & NM_031168 & ACTGAACCTGACCGTACATCGGCAAACCTAGTGCGTTA & AGGAATGTCCACAAACTGATATGC \\
INOS & NM_010927 & ACTGAACCTGACCGTACAGCATCCCAAGTACGAGTGGTTC & AGTGCATACCACTTCAACCCG \\
IRF3 & NM_016849 & ACTGAACCTGACCGTACATCAAGGTTGTTCCTACATGTCTTAAGG & CTTCCCGGGCCATCTCTAAC \\
LIF & NM_008501.2 & ACTGAACCTGACCGTACAGCTGTATCGGATGGTCGCAT & CGGGTGATATTGGTCAGGGA \\
OSM & NM_001013365.1 & ACTGAACCTGACCGTACACACTCTTGGAGCCCTATATCCG & TCAGGTCAGGTGTGTTCAGGTTT \\
18S RNA & X56974 & ACTGAACCTGACCGTACATGCATGTCTAAGTACGCACGG & AATGAGCCATTCGCAGTTTCA \\
\hline
\end{tabular}

\section{Results}

Time-Related Expression of TLR2 in Response to Intracerebral LPS Injection

A single LPS injection into parenchyma of WT mice induced a rapid and sustained induction of TLR $2 \mathrm{mRNA}$ expression (fig. 1). Saline injection also caused a rapid and transient increase of TLR $2 \mathrm{mRNA}$ expression (fig. 1c), which is mainly due to the implantation of the infusion system into the dorsal basal ganglia. The signal is localized to the injection site and rapidly vanished after the injection of the control solution. In contrast, TLR2 mRNA was strongly up-regulated $6 \mathrm{~h}$ after LPS injection in almost the entire hemisphere (fig. 1e). Positive TLR2 cells were found across the cerebral tissue ipsilateral to the injection site and in area bordering the ventricles of the contralateral part (fig. 1e). At $24 \mathrm{~h}$ after LPS administration, the hybridization signal was only observed in proximity to the injection site (fig. 1f; table $3 \mathrm{~b}, \mathrm{~d}$ ), although a second wave of gene expression took place 2 days after the single endotoxin challenge (fig. 1g-i). At days 2 and 4, both the intensity and distribution of the signal increased (fig. 1g, h; table 3b, d) and slowly decreased thereafter (fig. 1i, j).

LPS Response Is Not Impaired in TLR2-Deficient Mice We then speculated that such a robust induction of TLR2 might modulate the effects of LPS on the immune response in the brain. To determine the role of TLR2, we injected the endotoxin in the brains of WT and TLR2deficient mice and measured the expression of Iк $\mathrm{B} \alpha$ (index of NF- $\kappa$ B activity), several cytokines/chemokines (IL-12, TNF $\alpha$, MCP1 and TGF $\beta 1$ ) and the LPS receptor CD14 (fig. 2). The single LPS bolus stimulated the expression of all these transcripts in the ipsilateral side of injection. Positive hybridization signals spread to the area from the prefrontal cortex to the end of the hippocampus formation (data not shown). There were no major differences in the intensity and distribution of the signals for all the genes between WT and TLR2-deficient mice.

As depicted by the figure 2, the expression of immune genes was quite similar in the brain of WT (left column) and TLR2-deficient mice (middle column) in response to LPS. IкB $\alpha$, CD14, IL-12, TGF- $\beta 1$ and MCP1 mRNA levels were not significantly different between the 2 groups of mice at any the time after LPS injection (fig. 2, right column; table $3 \mathrm{a}, \mathrm{c})$. However, the intensity of the TNF- $\alpha$ mRNA signal was lower in TLR2-deficient mice $6 \mathrm{~h}$ after the LPS challenge. No significant differences were reached for this transcript at other times after injection (table $3 \mathrm{a}$, c). These data indicate that although TLR 2 mRNA is strongly induced by the TLR4 ligand LPS, it does not play a major role in the immune reaction to the endotoxin in the CNS.

We have previously reported that LPS-induced the expression of innate immune genes in microglia. Figure 3 depicts a representative example of such a phenomenon for the cytokine IL-1 $\beta$. Immunohistochemistry using an antiserum directed against ibal (a marker of microglia) was combined with radioactive in situ hybridization for IL-1 $\beta$ mRNA (agglomeration of silver grains). The distribution and number of microglia were also similar in the ipsilateral side of both mouse groups $6 \mathrm{~h}$ after the LPS injection (fig. 3a, b). Moreover, all IL-1-expressing cells colocalized with the ibal-immunoreactive signal in the brain of both WT and TLR2-deficient mice in response to LPS (fig. 3c, d). These results suggest that microglia responded normally to the endotoxin in a context of TLR2 deficiency.

LPS-Induced Gene Expression in a MyD88-Dependent Pathway

MyD88 is a major signaling protein for most TLRs, but LPS can induce gene expression via MyD88-dependent 

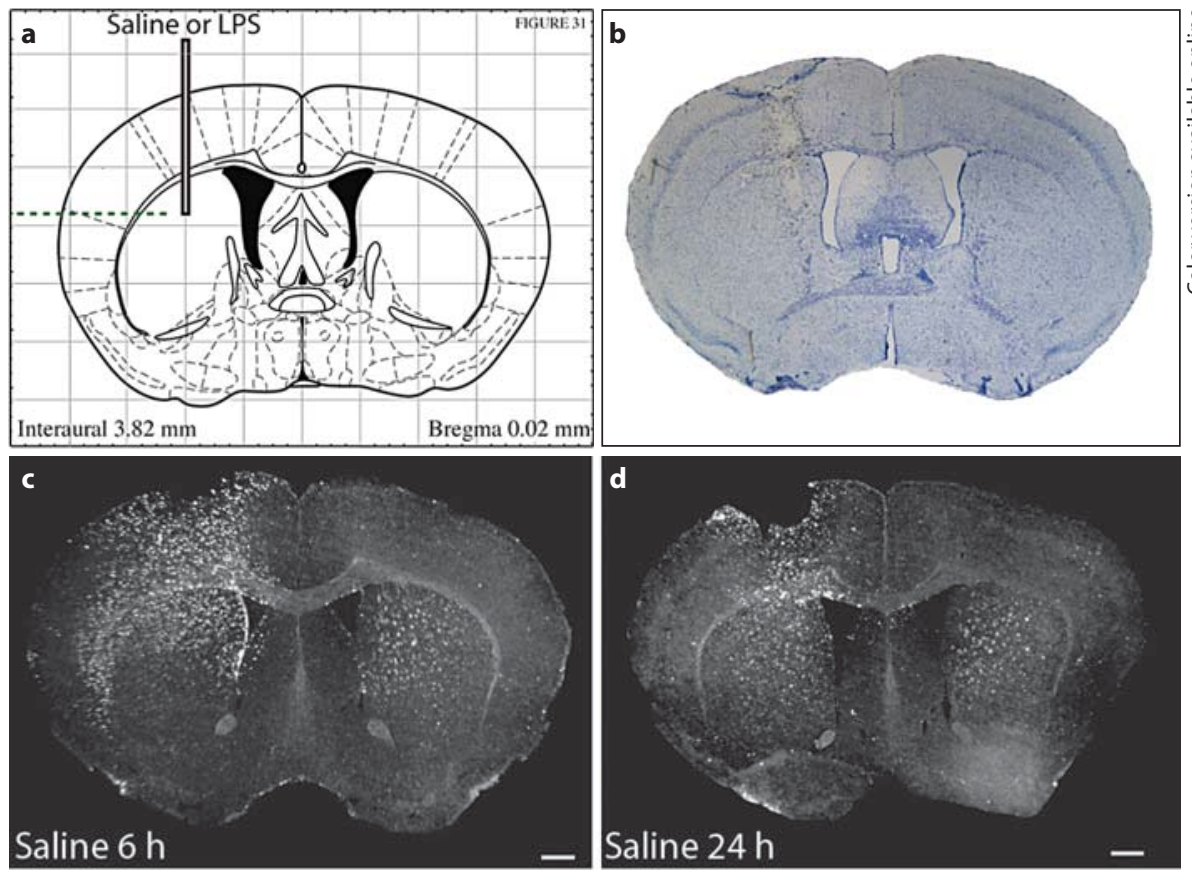

Fig. 1. Time-related expression of TLR 2 in response to LPS. These images are representative examples of the hybridization signal for TLR2 $\mathrm{mRNA}$ in the brain of WT mice after a single intraparenchymal injection with either saline $(1 \mu \mathrm{l})$ or LPS $(1 \mu \mathrm{g})$. The injection site is represented on a coronal section taken from Paxinos and Franklin [26] (a) and thionin-stained mouse brain (b). Darkfield photomicrographs show the pattern of TLR 2 signal $6 \mathrm{~h}$ (c) and $24 \mathrm{~h}$ (d) following saline injection and at time $6 \mathrm{~h} \mathrm{(e),} 24 \mathrm{~h}(\mathbf{f}), 2$ days (g), 4 days (h) and 10 days (i) after LPS challenge. Scale bar $=500 \mu \mathrm{m}$. $\mathbf{j}$ Semi-quantitative data (surface with a positive signal in arbitrary units) are shown. Data are means \pm SEM, $\mathrm{n}=3$ or $4 .{ }^{* *} \mathrm{p}<0.01,{ }^{* * *} \mathrm{p}<0.001$, vs. saline at the respective time point.
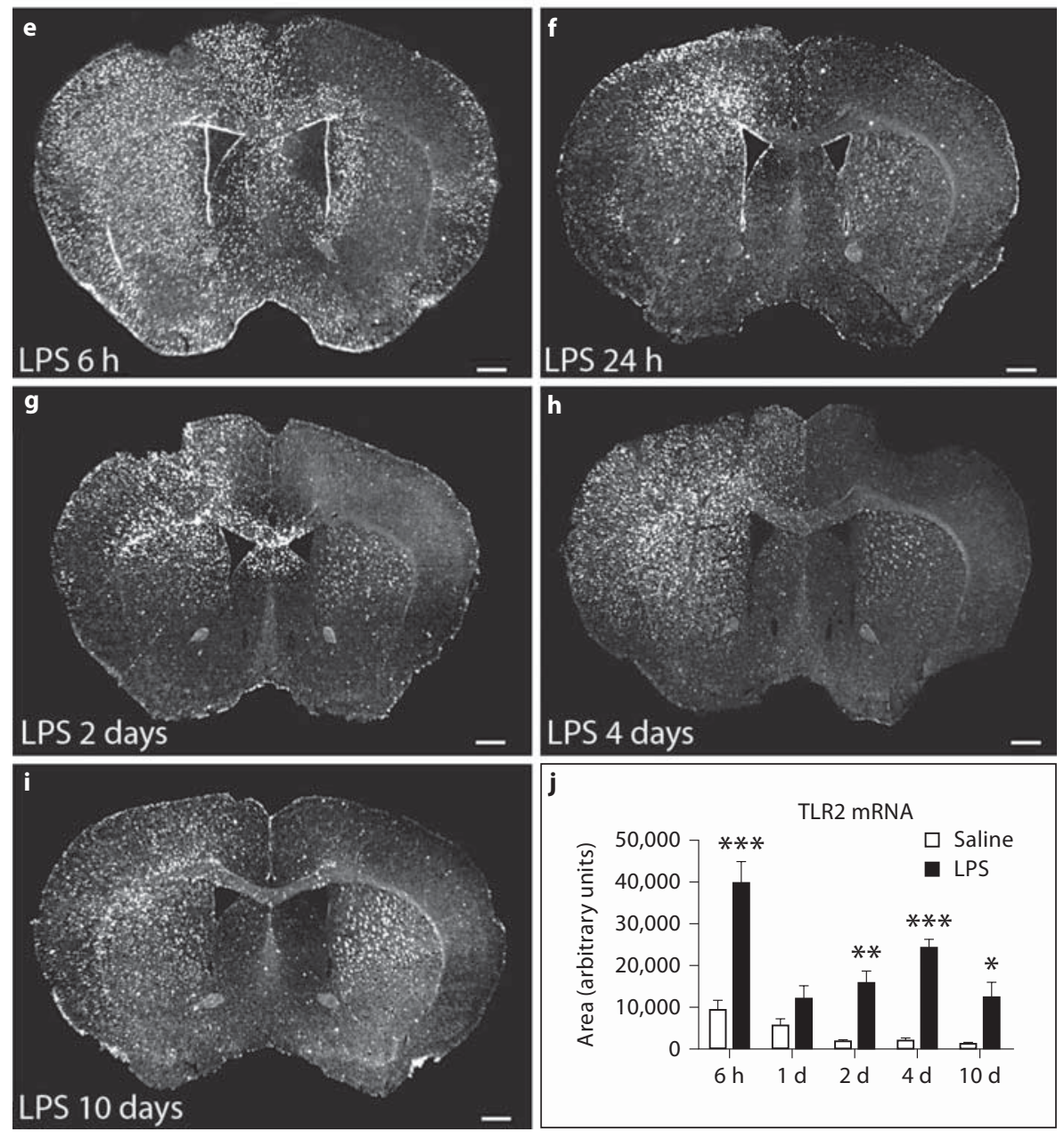
Table 3. Time-related expression of innate immune genes in the brain of WT, TLR $2 \mathrm{KO}$ and MyD88 KO mice following a single LPS infusion.

a Hybridization signal intensity in optical densities, WT vs. TLR2 KO

\begin{tabular}{|c|c|c|c|c|c|c|c|c|c|c|}
\hline \multirow[t]{2}{*}{ mRNA } & \multicolumn{2}{|l|}{$6 \mathrm{~h}$} & \multicolumn{2}{|l|}{$24 \mathrm{~h}$} & \multicolumn{2}{|c|}{2 days } & \multicolumn{2}{|c|}{4 days } & \multicolumn{2}{|c|}{10 days } \\
\hline & WT & TLR2 KO & WT & TLR2 KO & $\mathrm{WT}$ & TLR2 KO & WT & TLR2 KO & WT & TLR2 KO \\
\hline ІкB $\alpha$ & $=$ & $=$ & $\uparrow \uparrow \uparrow$ & $\uparrow \uparrow \uparrow$ & $\uparrow \uparrow$ & $\uparrow \uparrow \uparrow$ & $=$ & $=$ & $=$ & $=$ \\
\hline TNF- $\alpha$ & $\uparrow \uparrow \uparrow$ & $\uparrow \uparrow \uparrow$ & $\uparrow \uparrow \uparrow$ & $\uparrow \uparrow$ & $\uparrow \uparrow$ & $\uparrow \uparrow$ & $=$ & $=$ & $\downarrow$ & $\downarrow$ \\
\hline IL-12 & $\uparrow \uparrow$ & $\uparrow$ & $\downarrow$ & $\downarrow$ & $\downarrow$ & $\downarrow$ & $\downarrow$ & $\downarrow$ & $\downarrow$ & $\downarrow$ \\
\hline MCP1 & $\uparrow$ & $=$ & $\uparrow$ & $=$ & $=$ & $=$ & $=$ & $=$ & $\downarrow$ & $\downarrow$ \\
\hline CD14 & $=$ & $=$ & $\uparrow \uparrow$ & $=$ & $\uparrow$ & $\uparrow$ & $=$ & $=$ & $=$ & $=$ \\
\hline TGF- $\beta 1$ & $\downarrow$ & $\downarrow$ & $=$ & $=$ & $\uparrow \uparrow$ & $\uparrow$ & $=$ & $=$ & $=$ & $=$ \\
\hline
\end{tabular}

b Hybridization signal intensity in optical densities, WT vs. MyD88 KO

\begin{tabular}{|c|c|c|c|c|c|c|c|c|c|c|}
\hline \multirow[t]{2}{*}{ mRNA } & \multicolumn{2}{|l|}{$6 \mathrm{~h}$} & \multicolumn{2}{|l|}{$24 \mathrm{~h}$} & \multicolumn{2}{|c|}{2 days } & \multicolumn{2}{|c|}{4 days } & \multicolumn{2}{|c|}{10 days } \\
\hline & WT & MyD88 KO & WT & MyD88 KO & WT & MyD88 KO & WT & MyD88 KO & WT & MyD88 KO \\
\hline IкB $\alpha$ & $\uparrow \uparrow$ & $=$ & $\uparrow$ & $=$ & $=$ & $=$ & $=$ & $=$ & $=$ & $=$ \\
\hline TNF- $\alpha$ & $\uparrow \uparrow \uparrow$ & $=$ & $\uparrow$ & $=$ & $=$ & $=$ & $=$ & $=$ & $\downarrow$ & $\downarrow$ \\
\hline IL-12 & $=$ & $=$ & $\downarrow$ & $\downarrow$ & $\downarrow$ & $\downarrow$ & $\downarrow$ & $\downarrow$ & $\downarrow$ & $\downarrow$ \\
\hline MCP1 & $=$ & $=$ & $=$ & $=$ & $=$ & $=$ & $=$ & $=$ & $\downarrow$ & $\downarrow$ \\
\hline CD14 & $\uparrow \uparrow \uparrow$ & $=$ & $=$ & $=$ & $=$ & $=$ & $=$ & $=$ & $=$ & $=$ \\
\hline TGF- $\beta 1$ & $\downarrow$ & $\downarrow$ & $=$ & $=$ & $\uparrow$ & $=$ & $=$ & $=$ & $=$ & $=$ \\
\hline TLR2 & $=$ & $=$ & $=$ & $=$ & $\uparrow \uparrow \uparrow$ & $=$ & $=$ & $=$ & $=$ & $=$ \\
\hline
\end{tabular}

c Surface area with positive hybridization signal, WT vs. TLR2 KO

\begin{tabular}{|c|c|c|c|c|c|c|c|c|c|c|}
\hline \multirow[t]{2}{*}{ mRNA } & \multicolumn{2}{|l|}{$6 \mathrm{~h}$} & \multicolumn{2}{|l|}{$24 \mathrm{~h}$} & \multicolumn{2}{|c|}{2 days } & \multicolumn{2}{|c|}{4 days } & \multicolumn{2}{|c|}{10 days } \\
\hline & WT & TLR2 KO & WT & TLR2 KO & WT & TLR2 KO & WT & TLR2 KO & WT & TLR2 KO \\
\hline IкB $\alpha$ & $=$ & $=$ & $\uparrow \uparrow \uparrow$ & $\uparrow \uparrow \uparrow$ & $\uparrow \uparrow \uparrow$ & $\uparrow \uparrow \uparrow$ & $=$ & $=$ & $=$ & $=$ \\
\hline TNF- $\alpha$ & $=$ & $=$ & $\uparrow \uparrow \uparrow$ & $\uparrow \uparrow \uparrow$ & $\uparrow \uparrow \uparrow$ & $\uparrow \uparrow \uparrow$ & $=$ & $=$ & $\downarrow$ & $\downarrow$ \\
\hline IL-12 & $\uparrow \uparrow \uparrow$ & $\uparrow \uparrow$ & $\downarrow$ & $\downarrow$ & $\downarrow$ & $\downarrow$ & $\downarrow$ & $\downarrow$ & $\downarrow$ & $\downarrow$ \\
\hline MCP1 & $=$ & $\uparrow \uparrow$ & $\uparrow \uparrow \uparrow$ & $\uparrow \uparrow \uparrow$ & $\uparrow \uparrow \uparrow$ & $\uparrow \uparrow \uparrow$ & $=$ & $=$ & $\downarrow$ & $\downarrow$ \\
\hline CD14 & $\uparrow$ & $\uparrow$ & $\uparrow \uparrow \uparrow$ & $\uparrow$ & $\uparrow \uparrow \uparrow$ & $\uparrow \uparrow \uparrow$ & $=$ & $=$ & $=$ & $=$ \\
\hline TGF- $\beta 1$ & $\downarrow$ & $\downarrow$ & $=$ & $=$ & $\uparrow \uparrow \uparrow$ & $\uparrow \uparrow \uparrow$ & $\uparrow$ & $=$ & $=$ & $=$ \\
\hline
\end{tabular}

d Surface area with positive hybridization signal, WT vs. MyD88 KO

\begin{tabular}{|c|c|c|c|c|c|c|c|c|c|c|}
\hline \multirow[t]{2}{*}{ mRNA } & \multicolumn{2}{|l|}{$6 \mathrm{~h}$} & \multicolumn{2}{|l|}{$24 \mathrm{~h}$} & \multicolumn{2}{|c|}{2 days } & \multicolumn{2}{|c|}{4 days } & \multicolumn{2}{|c|}{10 days } \\
\hline & $\mathrm{WT}$ & MyD88 KO & WT & MyD88 KO & $\mathrm{WT}$ & MyD88 KO & WT & MyD88 KO & WT & MyD88 KO \\
\hline I $\kappa \mathrm{B} \alpha$ & $\uparrow \uparrow \uparrow$ & $=$ & $=$ & $=$ & $\uparrow$ & $=$ & $=$ & $=$ & $=$ & $=$ \\
\hline TNF- $\alpha$ & $\uparrow \uparrow$ & $=$ & $=$ & $=$ & $\uparrow \uparrow$ & $=$ & $=$ & $=$ & $\downarrow$ & $\downarrow$ \\
\hline IL-12 & $\uparrow \uparrow \uparrow$ & $=$ & $\downarrow$ & $\downarrow$ & $\downarrow$ & $\downarrow$ & $\downarrow$ & $\downarrow$ & $\downarrow$ & $\downarrow$ \\
\hline MCP1 & $\uparrow$ & $=$ & $=$ & $=$ & $=$ & $=$ & $=$ & $=$ & $\downarrow$ & $\downarrow$ \\
\hline CD14 & $\uparrow \uparrow \uparrow$ & $\uparrow$ & $=$ & $=$ & $\uparrow \uparrow \uparrow$ & $=$ & $\uparrow \uparrow \uparrow$ & $=$ & $=$ & $=$ \\
\hline TGF- $\beta 1$ & $\downarrow$ & $\downarrow$ & $=$ & $=$ & $\uparrow \uparrow$ & $=$ & $\uparrow \uparrow \uparrow$ & $=$ & $=$ & $=$ \\
\hline TLR2 & $\uparrow \uparrow \uparrow$ & $=$ & $=$ & $=$ & $\uparrow \uparrow$ & $=$ & $\uparrow \uparrow \uparrow$ & $=$ & $\uparrow$ & $=$ \\
\hline
\end{tabular}

$\uparrow$ Up regulation; = no variation; $\downarrow$ no signal, when compared with their respective saline-treated groups. The number of arrows number reflects statistical analyses: 1 arrow $=\mathrm{p}<0.05 ; 2$ arrows $=\mathrm{p}<0.01 ; 3$ arrows $=\mathrm{p}<0.001$, vs. their respective saline groups. 

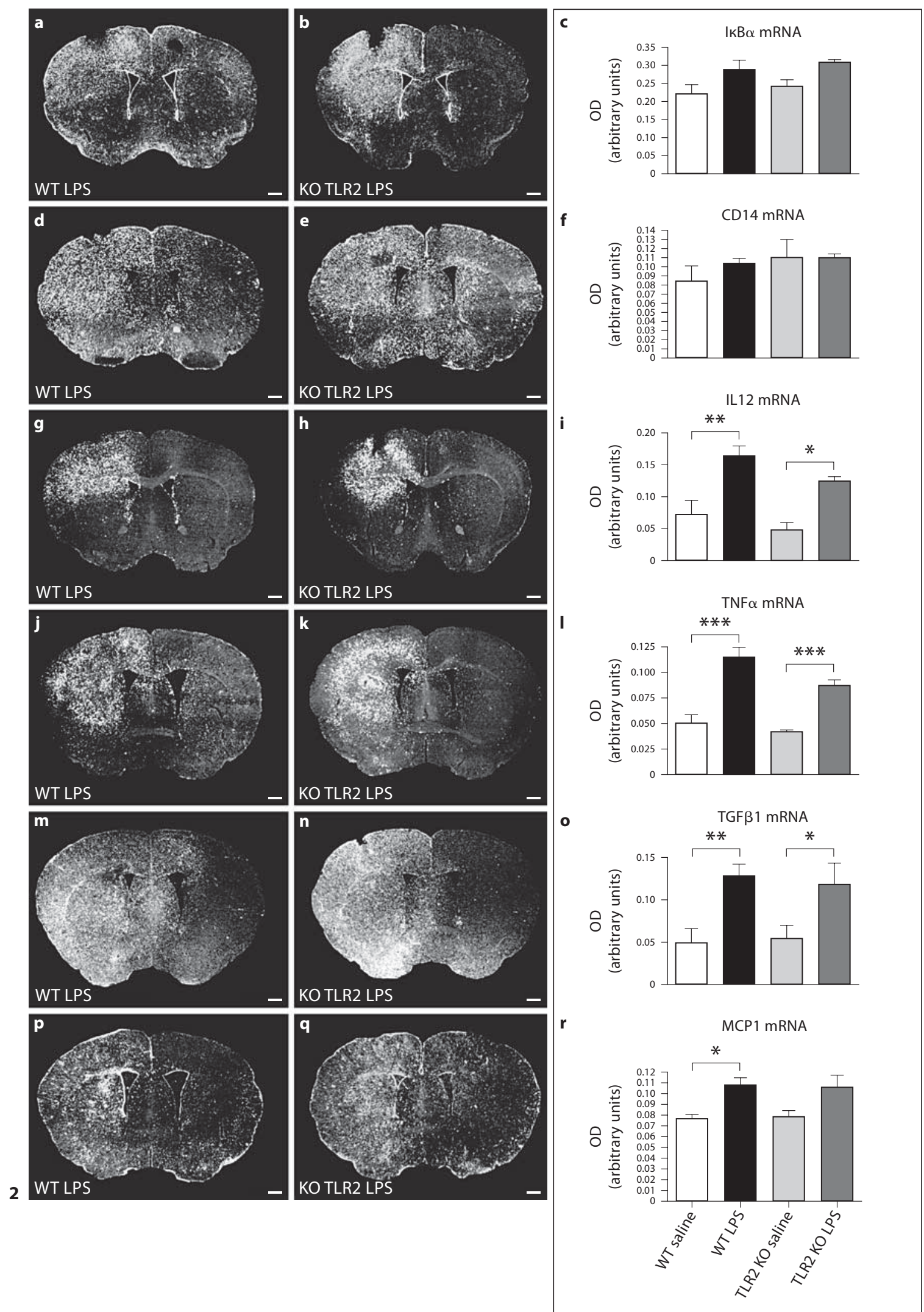
and independent pathways. This role of MyD88 in the brain has yet to be fully characterized. Figure 4 depicts the pattern of IкB $\alpha$ expression $6 \mathrm{~h}$ (left column) and $24 \mathrm{~h}$ (right column) after LPS injection. As for the previous experiment, a marked hybridization signal for IкB $\alpha$ was observed in the ipsilateral side of WT mice 6 and $24 \mathrm{~h}$ after the LPS treatment. Such IкB $\alpha$ induction was completely abolished in the brain of MyD88-deficient mice (fig. $4 \mathrm{a}-\mathrm{d}$ ). Quantitative analyses of Iк $\mathrm{B} \alpha$ signal intensity (fig. 4e, f) and distribution (fig. 4g, h) indicated similar mRNA levels in the brain of MyD88-deficient mice treated with either vehicle or LPS. These results were confirmed by real-time qPCR performed on RNA extracted from the brain of mice killed $6 \mathrm{~h}$ (fig. $4 \mathrm{i}$ ) and $24 \mathrm{~h}$ (fig. $4 \mathrm{j}$ ) after LPS challenge.

These data provide significant evidence that NF- $\mathrm{B}$ signaling is inhibited in the brain of MyD88-deficient mice. We next determined the expression levels of po-

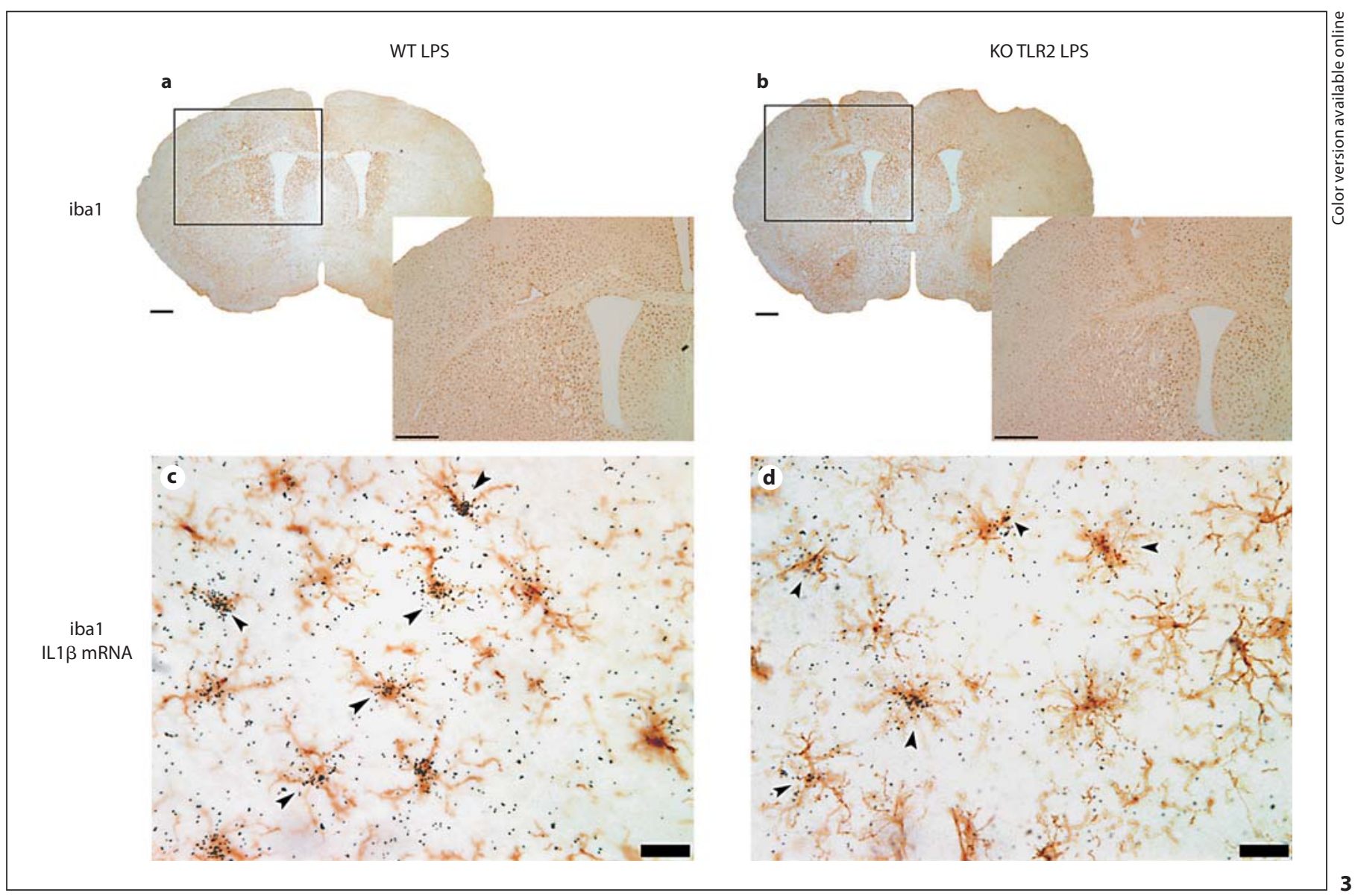

Fig. 2. Effects of LPS on the expression of immune genes in the brain of WT and TLR2-deficient mice. These images are darkfield photomicrographs taken from NTB-2 dipped emulsion slides, which were previously hybridized with radioactive cRNA probe

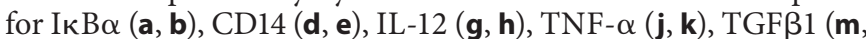
n) and MCP-1 (p, q). Optical Densities (OD; $\mathbf{c}, \mathbf{f}, \mathbf{i}, \mathbf{I}, \mathbf{o}, \mathbf{r})$ were measured at $6 \mathrm{~h}$ after injection, except for TGF- $\beta 1$ which was induced later and measured at 2 days. Note that both groups of mice responded similarly to the endotoxin challenge. Data in histograms are means (arbitrary units) \pm SEM, $\mathrm{n}=3$ or $4 .{ }^{*} \mathrm{p}<0.05$, ${ }^{* *} \mathrm{p}<0.01,{ }^{* * *} \mathrm{p}<0.001$, vs. respective saline group. In images, scale bar $=500 \mu \mathrm{m}$.
Fig. 3. Microglia expresses cytokine transcripts in WT and TLR2deficient mice $6 \mathrm{~h}$ after a single LPS injection. Brown cells are immunoreactive microglia stained with an anti-ibal antibody and peroxidase-conjugated secondary antibody. The sections were thereafter hybridized with a mouse IL-1 $\beta$ cRNA probe and dipped into NTB2 emulsion milk (silver grains). IL-1 $\beta$ (agglomeration of silver grains) is clearly expressed in microglia in response to LPS in WT (c) and TLR2 ${ }^{-/-}$(d) mice. Black arrowheads indicate double-labeled cells (iba1/IL-1 $\beta$ mRNA). Scale bar $=500 \mu \mathrm{m}(\mathbf{a}, \mathbf{b})$ and $20 \mu \mathrm{m}(\mathbf{c}, \mathbf{d})$. 


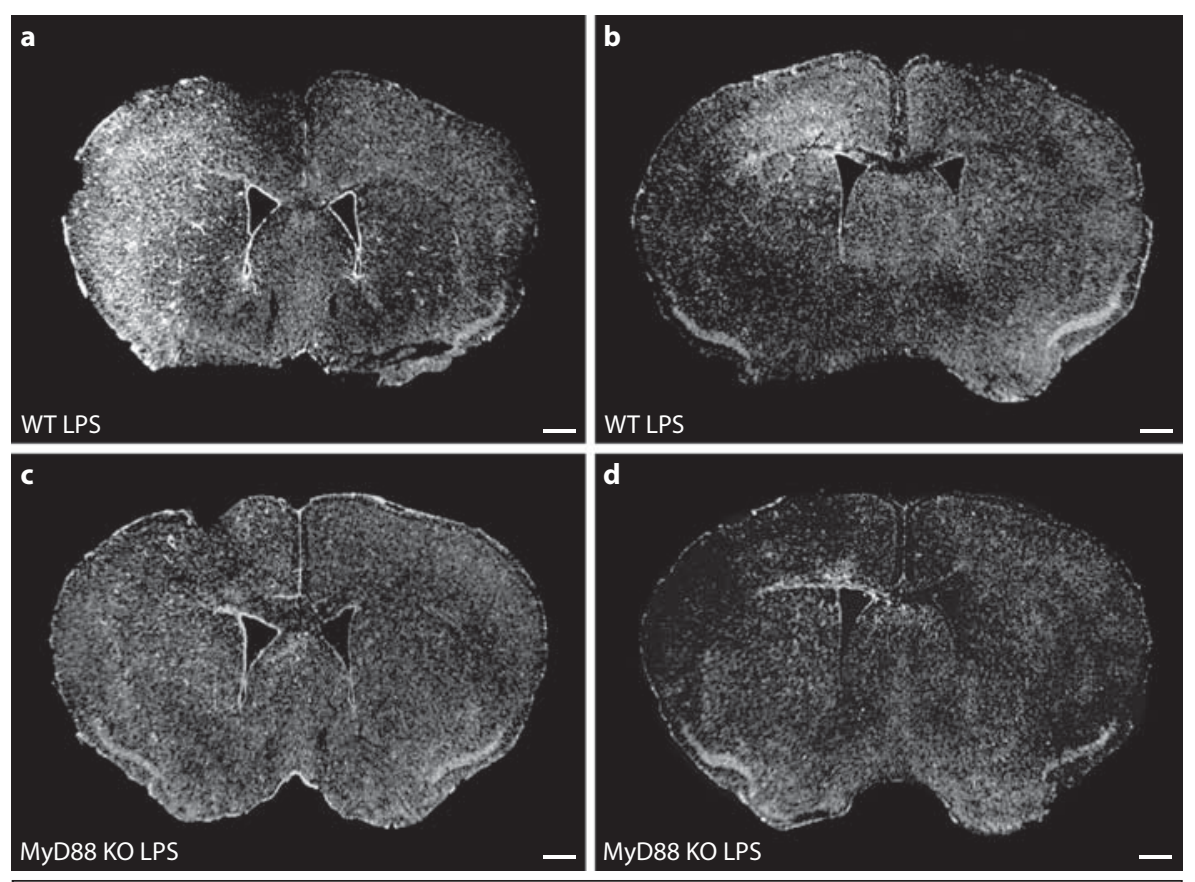

Fig. 4. MyD88-dependent induction of Iк $\mathrm{B} \alpha \mathrm{mRNA}$ in response to intracerebral LPS administration. Darkfield photomicrographs show I $\mathrm{B} \alpha$ mRNA expression at $6 \mathrm{~h}(\mathbf{a}, \mathbf{c})$ and $24 \mathrm{~h} \mathrm{(b,d)}$ after LPS injection in WT and MyD88-deficient mice. Mean OD $(\mathbf{e}, \mathbf{f})$ and mean of the surface with positive hybridization signal (area) $(\mathbf{g}, \mathbf{h})$ in WT or MyD88 KO mice 6 and $24 \mathrm{~h}$ after saline or LPS injection $(\mathrm{n}=3-4)$. I $\mathrm{B} \alpha \mathrm{mRNA}$ levels were also quantified by means of real time qPCR studies at $6 \mathrm{~h}$ (i) and $24 \mathrm{~h}(\mathbf{j})$ after injection $(\mathrm{n}=5)$. a-d Scale bar $=500 \mu \mathrm{m}$. e-j Results are expressed as means (arbitrary units) \pm SEM. ${ }^{*} \mathrm{p}<0.05,{ }^{* *} \mathrm{p}<0.01,{ }^{* *} \mathrm{p}<0.001$.
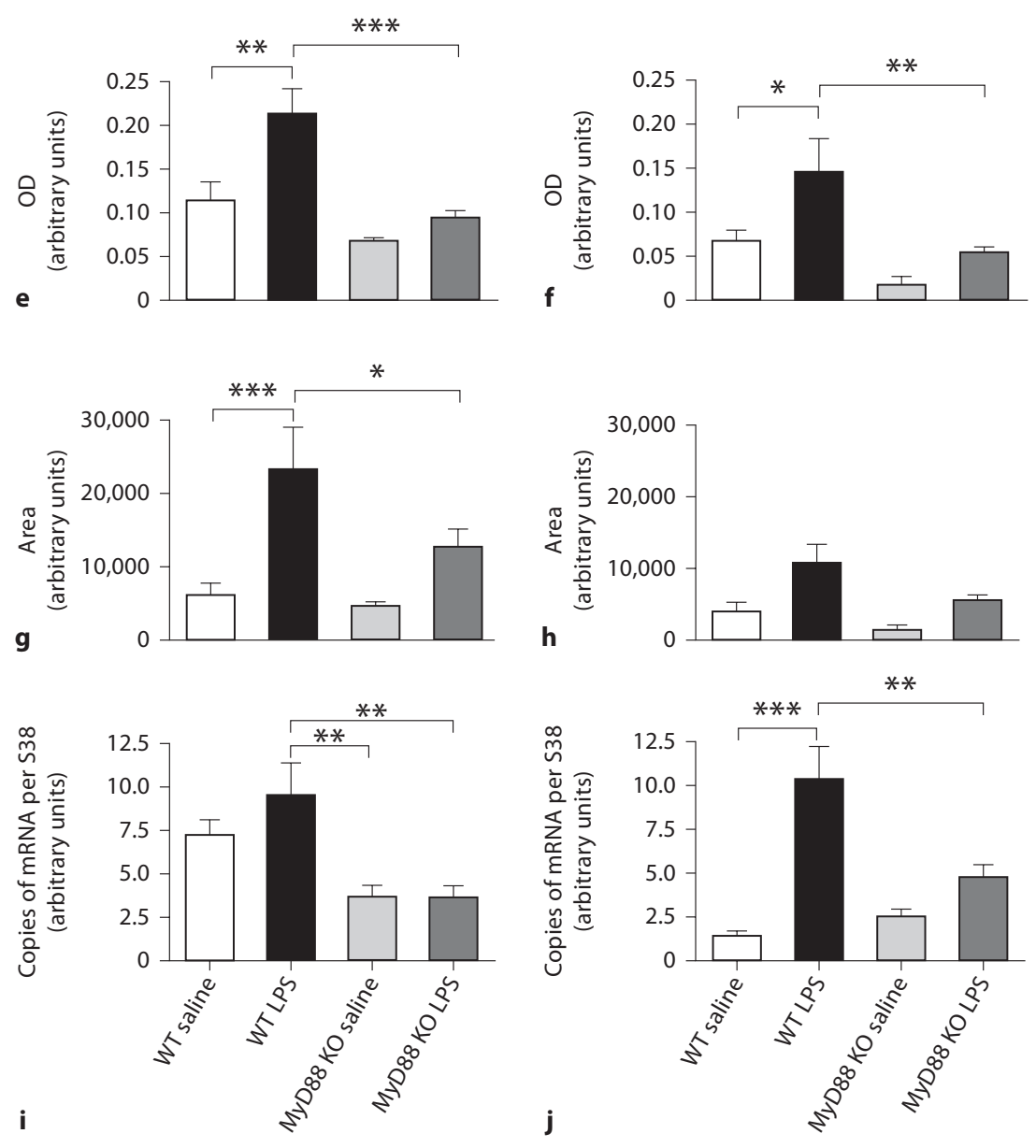
tential target genes that might be MyD88 and NF- $\mathrm{BB}$ dependent or independent. These include TNF $\alpha$, IL-12, TGF- $\beta 1$, MCP1, TLR2, CD14, inducible NO synthase (iNOS), IL-1 $\beta$, oncostatin M (OSM), leukemia inhibitory factor (LIF), IL-6 and interferon regulatory factor 3 (IRF-3) (fig. 5 and 6). As previously shown by in situ hybridization, LPS increased expression levels of TNF- $\alpha$, IL-12, TGF- $\beta 1$, MCP1, TLR2, CD14. These results were confirmed by RT-qPCR (data not shown). The increased expression in TNF- $\alpha$ (fig. 5a, b), IL-12 (fig. 5c, d), TGF$\beta 1$ (fig. 5e, f), MCP1 (fig. 5g, h), TLR2 (fig. 5i, j) and CD14 (fig. 5k, l) mRNA levels were significantly prevented in MyD88-deficient mice. Actually there was no induction at any of the times analyzed in this study (table $3 b, d)$.

We extended our analysis for cytokines of the IL-6-related subfamily (e.g. IL-6, OSM and LIF), iNOS, IL-1 $\beta$ and IRF-3. Save for IRF3, the CNS expression of all these transcripts was strongly up-regulated by LPS in a MyD88dependent manner (fig. 6). IRF-3 mRNA levels remained similar in the brain of WT and MyD88-deficient mice in response to the TLR4 ligand. These data provide very compelling evidence that the innate immune reaction to LPS is MyD88 dependent in cells of the CNS.

\section{Discussion}

The endotoxin LPS is the most frequently used model to stimulate the innate immune system in vitro and in vivo. When administered directly in the brain, it causes a rapid and transient expression of numerous inflammatory genes, which indicates that the CNS has an innate immune system on its own. Microglia plays a critical role in such a system, although immune genes have been reported in almost every cell type of the brain. However, TLR2 is expressed only in microglia in response to both systemic and cerebral LPS treatments [22, 29, 30]. We consequently speculated that this receptor was involved in the immune reaction to the endotoxin, but TLR2 $2^{-/-}$ and WT mice displayed a very similar pattern of immune genes in the CNS from $6 \mathrm{~h}$ to 10 days after injection. In contrast, $\mathrm{MyD} 88^{-/-}$mice did not mount an inflammatory reaction when exposed to the endotoxin in the CNS. It is interesting to note that TLR4 stimulation leads to TLR2 gene transcription through a MyD88 pathway in microglia and the receptor transcript is still detectable in the brain for up to 10 days after LPS treatment. Very few immune genes remained up-regulated for such a long period after a single LPS bolus.

Proinflammatory Signaling in the CNS
The mechanisms involved in this maintained TLR2 expression in the CNS have yet to be clarified. We have previously reported that the endotoxin is present in the cerebral tissue for several days after a single injection and that the profile of genes induced by LPS closely resembles the distribution of the lipid A part [19]. TLR4 may therefore be activated for numerous days after a single LPS administration. However, most genes measured in this study were no longer detected while the TLR2 signal was still present at day 10. Paracrine factors produced by microglia could participate in the ongoing expression of the gene encoding TLR2. Indeed, TNF- $\alpha$ is secreted by microglia following LPS exposure and it can act as a paracrine factor to further stimulate the immune cells of the brain [18]. Although TNF does not signal through MyD88, intracerebral treatment with the cytokine stimulates TLR2 gene transcription in microglia [31]. It is therefore possible that TNF or other secreted molecules take the relay to maintain TLR2 expression in the ipsilateral side. This concept fits very well with the 2 waves of TLR2 induction following a single LPS challenge. The question remaining is why TLR2 is completely inhibited in MyD88deficient mice if TNF is involved, which does not signal through MyD88. Since TNF transcript is no longer expressed in the brain of MyD88 ${ }^{-/-}$mice, it may then not participate in the second wave of TLR2 induction.

The ability of a TLR4 ligand to stimulate TLR2 gene expression can be explained by the fact that the mouse TLR2 promoter possesses a functional NF- $\kappa \mathrm{B}$ binding site [32]. Moreover, both TNF- $\alpha$ and IL-1 $\beta$ cytokines are able to induce TLR2 expression [33, 34]. TLR2 is also upregulated in macrophages following infection [29]. The spontaneous TLR2 induction could therefore be a natural process of the inflammatory conditions in cells of the innate immune system, but its physiological relevance in the CNS has yet to be uncovered. We have recently reported that TLR2 was selectively up-regulated by microglia in denervated zones of the hippocampus in response to a stereotaxic transection of axons in the entorhinal cortex [35]. There was a transient and selective reduction in lesion-induced expression of cytokines and chemokines in mice lacking TLR2 [35]. In addition, significantly fewer macrophages and leukocytes were recruited and/or activated in the sciatic nerve distal stump of TLR2-deficient mice compared to WT littermates, while recovery of locomotor function was impaired [36]. Locomotor recovery also was impaired in TLR2 ${ }^{-/-}$mice following spinal cord injury [37]. These data together clearly support a role of TLR2 signaling in neuroprotection and repair after injury.

J Innate Immun 2009;1:480-493 489 


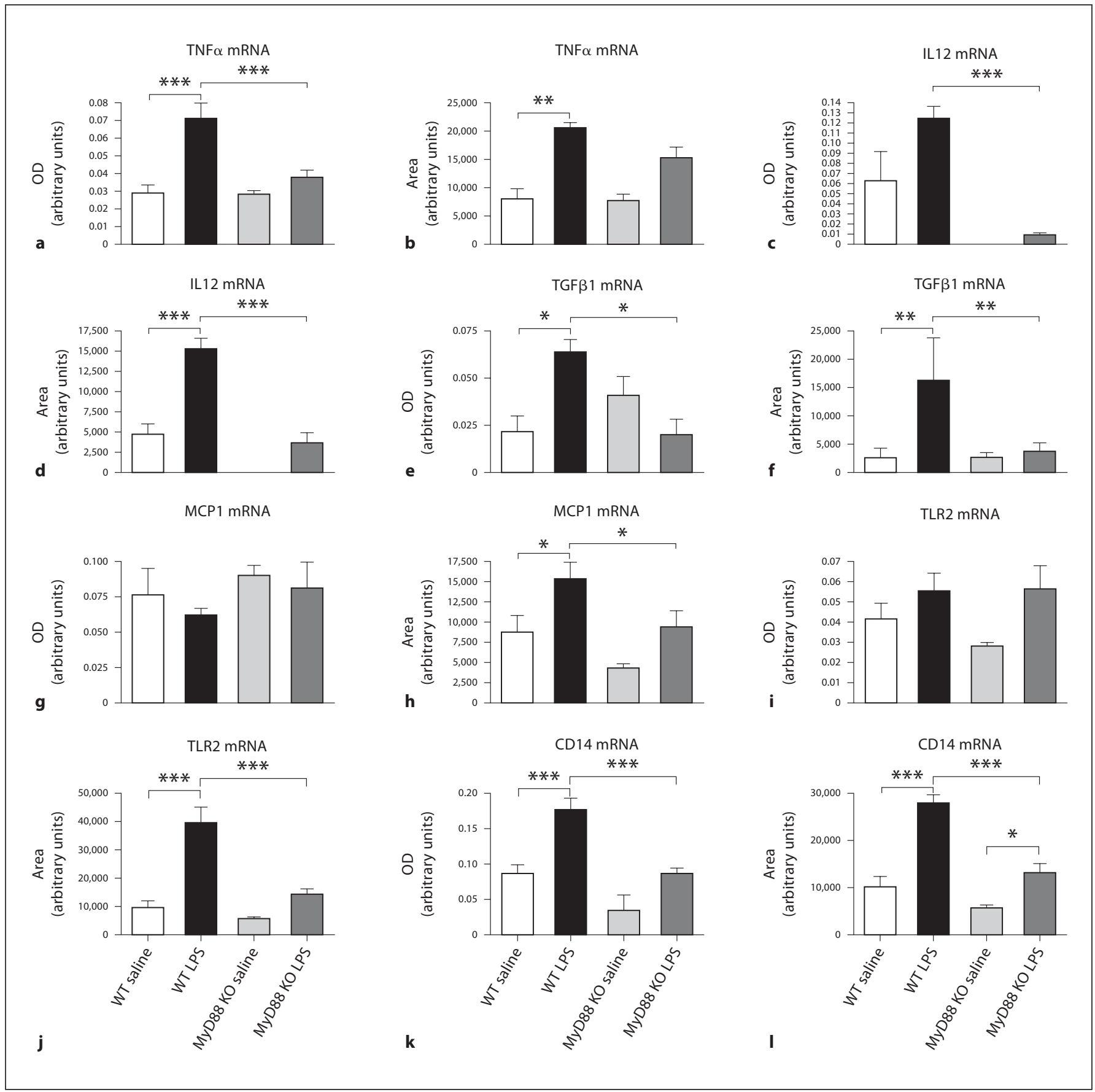

Fig. 5. Brain expression of innate immune genes is dependent on MyD88 signaling following a single LPS challenge. Hybridization signal intensities (OD) and surface area for TNF- $\alpha$ (a, b), IL-12 (c, d), TGF- $\beta 1$ (e, f), MCP1 $(\mathbf{g}, \mathbf{h})$, TLR2 $(\mathbf{i}, \mathbf{j})$ and CD14 $(\mathbf{k}, \mathbf{I})$ following saline or LPS injection in the brain of WT and MyD88-deficient mice. All quantifications were performed at time $6 \mathrm{~h}$, except TGF- $\beta 1$ which was induced later and quantified at 2 days. The results are expressed as means (arbitrary units) $\pm \mathrm{SEM}, \mathrm{n}=3$ or $4 .{ }^{*} \mathrm{p}<0.05,{ }^{* *} \mathrm{p}<0.01$, *** $\mathrm{p}<0.001$. 


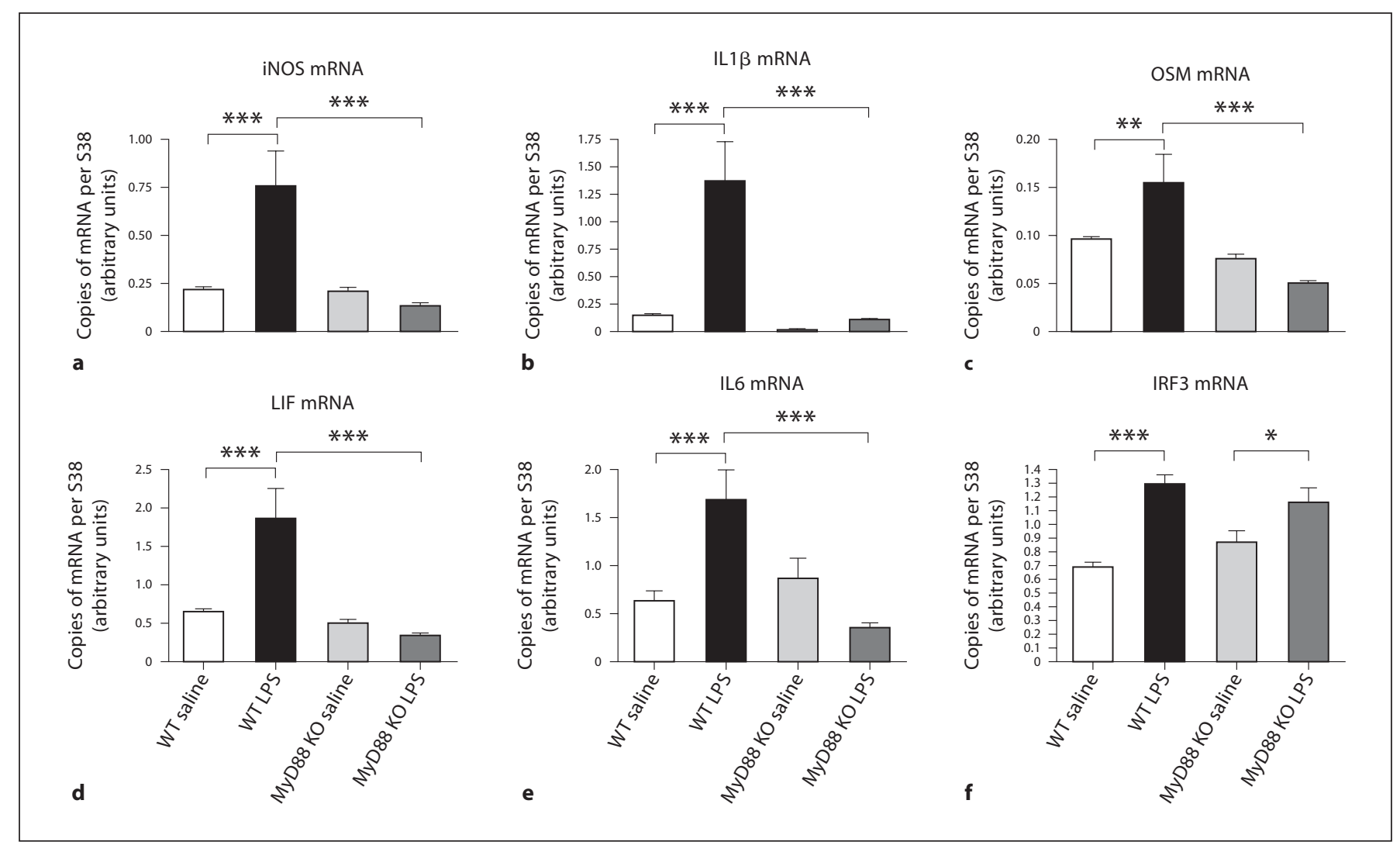

Fig. 6. MyD88-dependent and independent expression of immune genes in the brain of LPS-treated mice. The real-time qPCR analysis was performed on mRNAs extracted from brains of mice that received either saline or LPS and were killed $6 \mathrm{~h}$ afterwards, except IRF3 which was determined at time $24 \mathrm{~h}$. The qPCR data are shown for iNOS (a), IL-1ß (b), OSM (c), LIF (d), IL-6 (e) and IRF3 mRNA (f) in WT and MyD88-deficient mice ( $\mathrm{n}=$ 5). Please note that up-regulation of these transcripts are totally prevented in MyD88-deficient mice, except IRF3 which is a MyD88-independent transcription factor. The results are expressed as means (arbitrary units) \pm SEM. ${ }^{*} \mathrm{p}<0.05,{ }^{* *} \mathrm{p}<0.01,{ }^{* * *} \mathrm{p}<0.001$.

In addition to ligands produced by infectious microorganisms, few proteins of the host are believed to act as endogenous ligands for TLRs. This is the case for heat shock proteins 60 and 70 and fibrinogen, which are able to stimulate proinflammatory signaling via TLR4 and TLR2 [1, 12]. Recognition of these endogenous ligands is likely to be a natural defense mechanism for the host to mount an immune reaction in presence of damaged tissues or severely stressed cells. Numerous other endogenous ligands are likely to be uncovered in the years to come. Although TLR2 does not modulate the effects of LPS on immune cells of the brain, it may play a critical role in the recognition of these endogenous ligands produced by damaged cells in the brain. This would lead to a proper neuroinflammatory response in the context of brain injuries and diseases for the production of key im- mune molecules to clear debris and restore the milieu for improving recovery and repair.

NF- $\kappa \mathrm{B}$ activity and expression of a large family of inflammatory genes are triggered via the MyD88 signal transduction pathway. The results obtained in MyD88-deficient mice suggest that this adaptor protein plays a pivotal role in LPS-induced innate immunity in the CNS. Indeed, $\mathrm{MyD} 8^{-/-}$mice were essentially unresponsive to the intracerebral treatment with the endotoxin. MyD88 gene deletion completely prevented transcriptional activation of TNF $\alpha$, IL-1 $1 \beta$, IL-12 and MCP1 gene. Moreover, members of the IL- 6 subfamily - IL-6, LIF and OSM - were no longer induced in the brain of MyD88-deficient mice. This was also the case for the anti-inflammatory cytokine TGF$\beta 1$ and the enzyme iNOS. The biosynthesis of these innate immune molecules is therefore MyD88-dependent in the 
brain, at least when it is exposed to LPS. On the other hand, IRF-3 expression levels were similar in the brain of WT and MyD88 $8^{--}$mice treated with LPS, suggesting a MyD88-independent IRF-3 induction in response to TLR4 signaling. These data provide very clear evidence that the innate immune system of the brain is very similar to the classical immune system of the periphery.

In such a classical system, TLRs signal via the TIR domain that interacts with 5 TIR domain-containing adaptors, namely MyD88, MyD88-adaptor-like (MAL; also known as TIRAP), TIR-domain-containing adaptor protein inducing IFN- $\beta$ (TRIF, also known as TICAM1), TRIF-related adaptor molecule (TRAM, also known as TICAM2) and sterile $\alpha$ - and armadillo-motif containing protein [38]. TLR4-mediated signaling activates IRF-3 to induce IFN- $\beta$ and IFN-inducible genes, and this activation is under TRIF pathways concomitantly with TRAM activation (i.e. via MyD88-independent events) [39-41]. The innate immune system of the CNS is very similar to the systemic immune system, because all the genes analyzed in this study were repressed MyD88-deficient mice and that IRF-3 was still present. MyD88 is consequently very critical in mediating TLR4 signaling and expression of innate immune genes in the brain of living mice.
In conclusion, we have highlighted that a single LPS bolus in the brain caused a rapid and transient transcriptional activation of proinflammatory molecules and receptors. The robust induction of TLR 2 in microglia is not involved in LPS-induced signaling in the brain, but its expression is MyD88-dependent. Although TLR2 deficiency failed to modulate the LPS response, MyD88 gene deletion completely abolished the ability of the TLR4 ligand to stimulate inflammatory molecules by cells of the CNS. These cells have also a MyD88-independent system, because IRF-3 response remained intact in MyD88 $8^{-/-}$ mice.

\section{Acknowledgments}

The Canadian Institutes in Health Research (CIHR) supported this research. G.N. is supported by a postdoctoral fellowship from the Alzheimer Society of Canada. S.R. holds a Canadian Research Chair in Neuroimmunology. MyD88-deficient breeding pairs were generously obtained from Dr. S. Akira (Department of Host Defense, Research Institute for Microbial Diseases, Osaka University, Osaka, Japan). We acknowledge the contribution of the Gene Quantification Core Laboratory of the Centre de Génomique de Québec.

\section{References}

1 Akira S, Uematsu S, Takeuchi, O: Pathogen recognition and innate immunity. Cell 2006; 124:783-801.

-2 Glezer I, Simard AR, Rivest S: Neuroprotective role of the innate immune system by microglia. Neuroscience 2007;147:867-883.

-3 Turrin NP, Rivest S: Molecular and cellular immune mediators of neuroprotection. Mol Neurobiol 2006;34:221-242.

-4 Aloisi F: Immune function of microglia. Glia 2001;36:165-179.

5 Olson JK, Miller SD: Microglia initiate central nervous system innate and adaptive immune responses through multiple TLRs. J Immunol 2004;173:3916-3924.

6 Uematsu S, Akira S: Toll-like receptors and innate immunity. J Mol Med 2006;84:712725.

7 Uematsu S, Akira S: Toll-like receptors and type I interferons. J Biol Chem 2007;282: 15319-15323.

-8 Adachi O, Kawai T, Takeda K, Matsumoto M, Tsutsui H, Sakagami M, Nakanishi K, Akira S: Targeted disruption of the MyD88 gene results in loss of IL-1- and IL-18-mediated function. Immunity 1998;9:143-150.
\$ Kopp E, Medzhitov R: Recognition of microbial infection by Toll-like receptors. Curr Opin Immunol 2003;15:396-401.

10 Takeda K, Akira S: TLR signaling pathways. Semin Immunol 2004;16:3-9.

11 Takeda K, Akira S: Toll-like receptors in innate immunity. Int Immunol 2005;17:1-14.

12 Takeda K, Kaisho T, Akira S: Toll-like receptors. Annu Rev Immunol 2003;21:335-376.

$>13$ Medzhitov R, Preston-Hurlburt P, Janeway CA Jr: A human homologue of the Drosophila Toll protein signals activation of adaptive immunity. Nature 1997;388:394-397.

14 Poltorak A, He X, Smirnova I, Liu MY, Van Huffel C, Du X, Birdwell D, Alejos E, Silva M, Galanos C, Freudenberg M, Ricciardi-Castagnoli P, Layton B, Beutler B: Defective LPS signaling in $\mathrm{C} 3 \mathrm{H} / \mathrm{HeJ}$ and $\mathrm{C} 57 \mathrm{BL} / 10 \mathrm{ScCr}$ mice: mutations in Tlr4 gene. Science 1998; 282:2085-2088

15 Wright SD: Toll, a new piece in the puzzle of innate immunity. J Exp Med 1999;189:605609.
16 Kawasaki K, Akashi S, Shimazu R, Yoshida T, Miyake K, Nishijima M: Involvement of TLR4/MD-2 complex in species-specific lipopolysaccharide-mimetic signal transduction by Taxol. J Endotoxin Res 2001;7:232236.

17 Shimazu R, Akashi S, Ogata H, Nagai Y, Fukudome K, Miyake K, Kimoto M: MD-2, a molecule that confers lipopolysaccharide responsiveness on Toll-like receptor 4. J Exp Med 1999;189:1777-1782.

18 Nadeau S, Rivest S: Role of microglial-derived tumor necrosis factor in mediating CD14 transcription and nuclear factor kappa $B$ activity in the brain during endotoxemia. J Neurosci 2000;20:3456-3468.

19 Nadeau S, Rivest S: Endotoxemia prevents the cerebral inflammatory wave induced by intraparenchymal lipopolysaccharide injection: role of glucocorticoids and CD14. J Immunol 2002;169:3370-3381.

20 Nguyen MD, Julien JP, Rivest S: Innate immunity: the missing link in neuroprotection and neurodegeneration? Nature Rev Neurosci 2002;3:216-227. 
21 Glezer I, Lapointe A, Rivest S: Innate immunity triggers oligodendrocyte progenitor reactivity and confines damages to brain injuries. FASEB J 2006;20:750-752.

$\checkmark 22$ Laflamme N, Echchannaoui H, Landmann $\mathrm{R}$, Rivest S: Cooperation between toll-like receptor 2 and 4 in the brain of mice challenged with cell wall components derived from Gram-negative and Gram-positive bacteria. Eur J Immunol 2003;33:1127-1138.

-23 Laflamme N, Soucy G, Rivest S: Circulating cell wall components derived from Gramnegative, not Gram-positive, bacteria cause a profound induction of the gene-encoding Toll-like receptor 2 in the CNS. J Neurochem 2001;79:648-657.

-24 Wooten RM, Ma Y, Yoder RA, Brown JP, Weis JH, Zachary JF, Kirschning CJ, Weis JJ: Toll-like receptor 2 is required for innate, but not acquired, host defense to Borrelia burgdorferi. J Immunol 2002;168:348-355.

-25 Simard AR, Rivest S: Neuroprotective effects of resident microglia following acute brain injury. J Comp Neurol 2007;504:716-729.

26 Paxinos G, Franklin K: The Mouse Brain in Stereotaxic Coordinates, ed 2. San Diego, Academic Press, 2001.

-27 Laflamme N, Lacroix S, Rivest S: An essential role of interleukin-1beta in mediating NF-kappaB activity and COX-2 transcription in cells of the blood-brain barrier in response to a systemic and localized inflammation but not during endotoxemia. J Neurosci 1999;19:10923-10930.
28 Laflamme N, Rivest S: Toll-like receptor 4: the missing link of the cerebral innate immune response triggered by circulating Gram-negative bacterial cell wall components. FASEB J 2001;15:155-163.

29 Liu Y, Wang Y, Yamakuchi M, Isowaki S, Nagata E, Kanmura Y, Kitajima I, Maruyama I: Upregulation of toll-like receptor 2 gene expression in macrophage response to peptidoglycan and high concentration of lipopolysaccharide is involved in NF-kappa B activation. Infect Immun 2001;69:27882796.

30 Soucy G, Boivin G, Labrie F, Rivest S: Estradiol is required for a proper immune response to bacterial and viral pathogens in the female brain. J Immunol 2005; 174:63916398.

31 Blais V, Rivest S: Effects of TNF-alpha and IFN-gamma on nitric oxide-induced neurotoxicity in the mouse brain. J Immunol 2004 172:7043-7052.

32 Musikacharoen T, Matsuguchi T, Kikuchi T, Yoshikai Y: NF-kappa B and STAT5 play important roles in the regulation of mouse Tolllike receptor 2 gene expression. J Immunol 2001;166:4516-4524.

-33 Faure E, Thomas L, Xu H, Medvedev A, Equils O, Arditi M: Bacterial lipopolysaccharide and IFN-gamma induce Toll-like receptor 2 and Toll-like receptor 4 expression in human endothelial cells: role of NF-kappa $\mathrm{B}$ activation. J Immunol 2001;166:20182024.

>34 Wang T, Lafuse WP, Zwilling BS: Regulation of Toll-like receptor 2 expression by macrophages following Mycobacterium avium infection. J Immunol 2000;165:6308-6313.
35 Babcock AA, Wirenfeldt M, Holm T, Nielsen $\mathrm{HH}$, Dissing-Olesen L, Toft-Hansen H, Millward JM, Landmann R, Rivest S, Finsen B, Owens T: Toll-like receptor 2 signaling in response to brain injury: an innate bridge to neuroinflammation. J Neurosci 2006;26: 12826-12837.

>36 Boivin A, Pineau I, Barrette B, Filali M, Vallieres N, Rivest S, Lacroix S: Toll-like receptor signaling is critical for Wallerian degeneration and functional recovery after peripheral nerve injury. J Neurosci 2007;27: 12396-12406.

37 Kigerl KA, Lai W, Rivest S, Hart RP, Satoskar AR, Popovich PG: Toll-like receptor (TLR)-2 and TLR-4 regulate inflammation, gliosis, and myelin sparing after spinal cord injury. J Neurochem 2007;102:37-50.

38 O'Neill LA, Bowie AG: The family of five: TIR-domain-containing adaptors in Tolllike receptor signalling. Nat Rev Immunol 2007;7:353-364.

39 Kaisho T, Akira S: Toll-like receptor function and signaling. J Allergy Clin Immunol 2006;117:979-987; quiz 988.

40 Kawai T, Adachi O, Ogawa T, Takeda K, Akira S: Unresponsiveness of MyD88-deficient mice to endotoxin. Immunity 1999;11:115122 .

41 Kawai T, Takeuchi O, Fujita T, Inoue J, Muhlradt PF, Sato S, Hoshino K, Akira S: Lipopolysaccharide stimulates the MyD88-independent pathway and results in activation of IFN-regulatory factor 3 and the expression of a subset of lipopolysaccharide-inducible genes. J Immunol 2001;167:5887-5894. 